\title{
Regional tectonic stress near the San Andreas fault in central and southern California
}

\author{
J. Townend \\ School of Earth Sciences, Victoria University of Wellington, Wellington, New Zealand
}

M. D. Zoback

Department of Geophysics, Stanford University, Stanford, California, USA

Received 23 October 2003; revised 18 December 2003; accepted 30 December 2003; published 29 July 2004.

[1] Throughout central and southern California, a uniform NNE-SSW direction of maximum horizontal compressive stress is observed that is remarkably consistent with the superposition of stresses arising from lateral variations in lithospheric buoyancy in the western United States, and farfield Pacific-North America plate interaction. In central California, the axis of maximum horizontal compressive stress lies at a high angle to the San Andreas fault (SAF). Despite relatively few observations near $( \pm 10 \mathrm{~km})$ the fault, observations in the greater San Francisco Bay area indicate an angle of as much as $85^{\circ}$, implying extremely low fault strength. In southern California, observations of stress orientations near the SAF are rotated slightly counterclockwise with respect to the regional field. Nevertheless, we observe an approximately constant angle between the SAF and the maximum horizontal stress direction of $68 \pm 7^{\circ}$ along $\sim 400 \mathrm{~km}$ of the fault, indicating that the SAF has moderately low frictional strength in southern California. INDEX TERMS: 8010 Structural Geology: Fractures and faults; 8020 Structural Geology: Mechanics; 8123 Tectonophysics: Dynamics, seismotectonics; 8164 Tectonophysics: Stresses-crust and lithosphere. Citation: Townend, J., and M. D. Zoback (2004), Regional tectonic stress near the San Andreas fault in central and southern California, Geophys. Res. Lett., 31, L15S11, doi:10.1029/2003GL018918.

\section{Introduction}

[2] It has been known for some time that stress orientations along the San Andreas fault (SAF) [Mount and Suppe, 1987; Zoback et al., 1987; Jones, 1988; Townend and Zoback, 2001] and the lack of a distinct heat flow anomaly at the trace of the fault [Lachenbruch and Sass, 1992, and references therein; Saffer et al., 2003] indicate average shear tractions less than 20$25 \mathrm{MPa}$ in the seismogenic upper crust. These observations are difficult to reconcile with typical frictional coefficients of common rock types $(\mu=0.6-1.0)$ such as are measured in laboratory settings [Byerlee, 1978] or inferred from deep borehole stress measurements [Townend and Zoback, 2000], which suggest shear tractions approximately five times as large. High frictional coefficients (commonly referred to as "Byerlee friction") imply an angle $(\beta)$ between the axis of maximum horizontal compression, $\mathrm{S}_{\mathrm{Hmax}}$, and the strike of a vertical strike-slip fault such as the San Andreas of $30-35^{\circ}$. Instead, what is typically observed throughout California is a much larger angle indicating near fault-normal compression in some places; such observations are especially noteworthy when the data come from crustal volumes immediately adjacent to the SAF [Jones, 1988; Oppenheimer et al., 1988; Zoback and Beroza, 1993; Townend and Zoback, 2001].

[3] The observed long-range (1000-5000 km) uniformity of stress orientations and relative magnitudes in intraplate regions suggests that plate-driving forces provide the largest component of the total stress field [Zoback et al., 1989; Zoback, 1992]. However, in some areas, including the western United States, stresses caused by lateral variations in crustal buoyancy appear to provide a large component of the horizontal stress field [Fleitout and Froidevaux, 1982; Jones et al., 1996]. How large, plate-bounding faults such as the SAF accomplish the slip required of them by global kinematics given ambient stresses is an outstanding question in crustal mechanics. In this study we compare different indicators of tectonic stress directions in central and southern California in order to put planned in situ stress measurements from the San Andreas Fault Observatory at Depth (SAFOD) drilling project in a regional context.

\section{Central California}

[4] Figure 1 illustrates crustal stress orientations in central California obtained from focal mechanism inversions [Townend and Zoback, 2001] and a variety of sources represented in the World Stress Map Database, most notably stress-induced wellbore breakouts in oil and gas wells [Fuchs and Müller, 2001]. The dashed trajectories are interpolations of $\mathrm{S}_{\mathrm{Hmax}}$ directions calculated by Flesch et al. [2000] using a variational technique to estimate the minimum deviatoric horizontal stress field resulting from lateral variations in gravitational potential energy (or lithospheric buoyancy) and deformation due to interaction between the North American and Pacific plates. Borehole breakout data, hydraulic fracture data, and focal mechanism stress inversion results reveal highly consistent $\mathrm{S}_{\mathrm{Hmax}}$ orientations at adjacent locations, a strong correlation with the computed $\mathrm{S}_{\mathrm{Hmax}}$ trajectories, and a very high angle between the $\mathrm{S}_{\mathrm{Hmax}}$ direction and the $\operatorname{SAF}\left(\beta \approx 85^{\circ}\right)$ along the San Francisco Peninsula. It is noteworthy that the Hayward, Calaveras and San Gregorio faults each appear to be as 


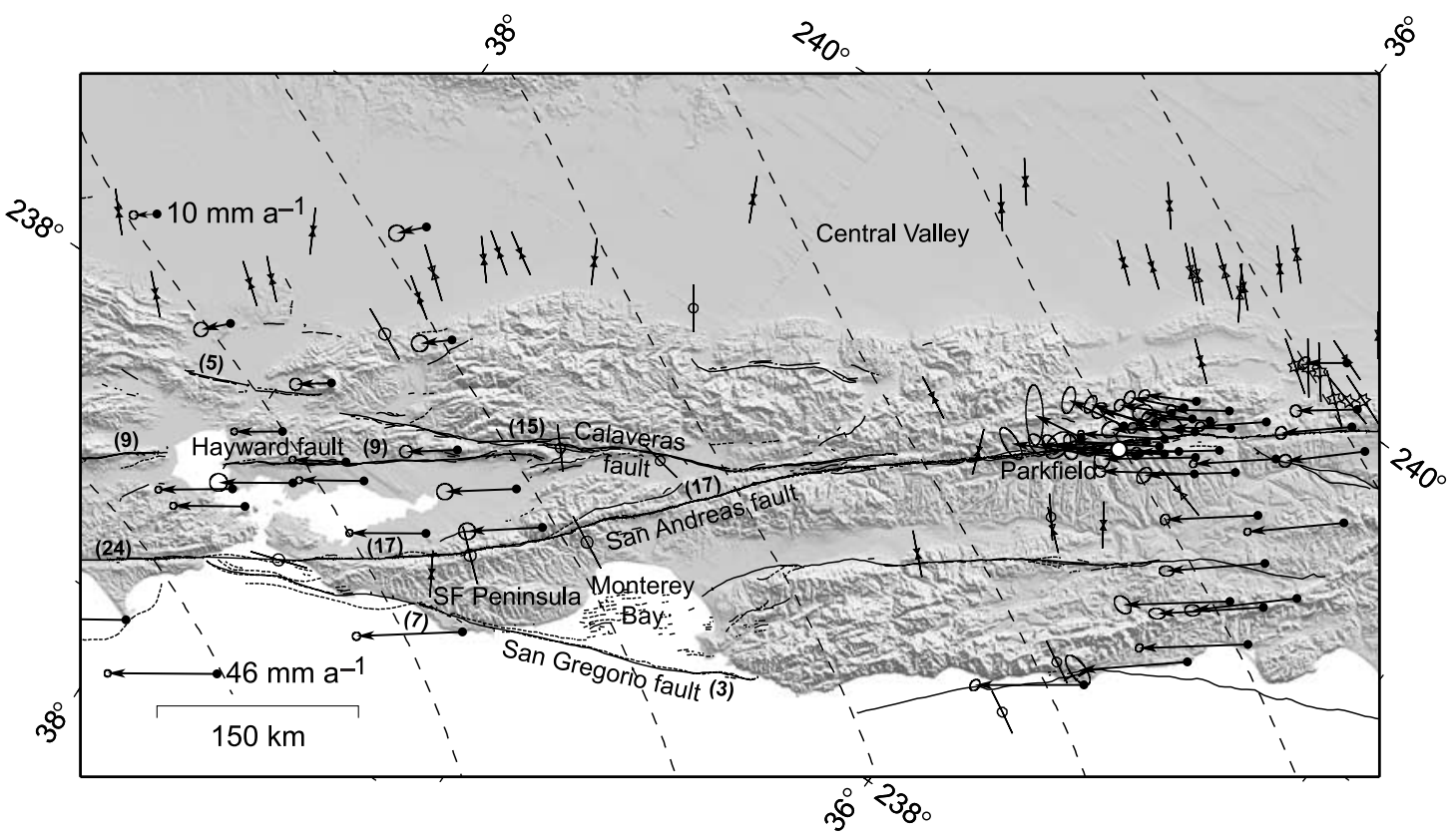

Figure 1. Maximum horizontal compression $\left(\mathrm{S}_{\mathrm{H} \max }\right)$ and crustal velocity data from central California shown in an oblique Mercator projection about the North America-Pacific Euler pole [DeMets et al., 1990]. $\mathrm{S}_{\mathrm{Hmax}}$ directions determined from borehole breakouts are shown by inward-pointing arrows, from hydraulic fracturing experiments by stars, and from earthquake focal mechanism inversions by split circles [Fuchs and Müller, 2001; Townend and Zoback, 2001]. The dashed trajectories show regional $\mathrm{S}_{\mathrm{Hmax}}$ directions calculated using a model of lithospheric buoyancy and plate interaction [Flesch et al., 2000], and the vectors illustrate crustal velocity data relative to North America [Murray and Segall, 2001]. The numbers in parentheses are Quaternary fault slip rates [Working Group on Earthquake Probabilities, 1999]. The SAFOD drillhole location is marked by a white circle. SF-San Francisco.

poorly oriented with respect to the contemporary stress field as the SAF itself [Schaff et al., 2002; Provost and Houston, 2003].

[5] The very high value of $\beta \sim 85^{\circ}$ observed along the San Francisco Peninsula is particularly interesting because the stress data were obtained from boreholes and focal mechanism stress inversions as close as $1 \mathrm{~km}$ to the fault's surface trace [Townend and Zoback, 2001]. Consequently, the ratio of shear to normal traction acting on the SAF in this area is very low. Assuming that the crust adjacent to the SAF is critically stressed [Townend and Zoback, 2000], we estimate the average shear traction acting on planes parallel to the SAF (evaluated at a depth of $7.5 \mathrm{~km}$ in a strike-slip stress regime using a crustal friction coefficient of 0.6) to be as little as $\sim 10 \mathrm{MPa}$ along the San Francisco Peninsula $(\beta=$ $85^{\circ}$ ), the effective normal traction to be $\sim 180 \mathrm{MPa}$, and the coefficient of friction to be an extremely low 0.06 . These estimates are compatible with those of Mount and Suppe [1987] and Zoback et al. [1987].

[6] Near Parkfield, the orientation of the regional stress field is highly compatible with stress measurements made in the SAFOD Pilot Hole [Hickman and Zoback, 2004], which indicate a clockwise rotation of $\mathrm{S}_{\mathrm{Hmax}}$ with depth to an angle of $\beta=70^{\circ}$ at $2.0-2.2 \mathrm{~km}$.

\section{Southern California}

[7] A map of southern California stress orientations is shown in Figure 2. As in central California, several important features of this map deserve specific mention: first, individual data sets produce remarkably consistent $\mathrm{S}_{\mathrm{Hmax}}$ estimates at relatively fine scales, as demonstrated particularly well by the cluster of near-parallel stress orientations obtained by focal mechanism stress inversion of seismicity that occurred after the 1994 Northridge earthquake $\left(241.4^{\circ} \mathrm{E}, 34.3^{\circ} \mathrm{N}\right)$, in the southern Sierra Nevada $\left(242.2^{\circ} \mathrm{E}, 35.9^{\circ} \mathrm{N}\right)$ and eastern Mojave Desert $\left(243.0^{\circ} \mathrm{E}\right.$, $35.0^{\circ} \mathrm{N}$ ), and by the clusters of borehole breakout and hydrofracture results in the southern San Joaquin Valley. Second, the results obtained using different techniques generally agree very well, in southern California as a whole but particularly in the southern San Joaquin Valley and near Los Angeles $\left(241.6^{\circ} \mathrm{E}, 34.0^{\circ} \mathrm{N}\right)$. Third, $\mathrm{S}_{\mathrm{H} \max }$ exhibits a relatively uniform NNE-SSW orientation at regional scales that is at approximately $60-70^{\circ}$ to the average strike of the SAF throughout southern California. Finally, there is remarkably good agreement between the observed stress field and the dynamical modeling results obtained independently by Flesch et al. [2000].

[8] No stress rotations near the SAF are apparent at the scale of these observations. An independent study that incorporates focal mechanism uncertainties explicitly [Abers and Gephart, 2001] substantiates this. The rose diagram inset in Figure 2 summarizes estimates of $\beta$ at 70 locations within $10 \mathrm{~km}$ of the SAF surface trace: the mean angle between $\mathrm{S}_{\mathrm{Hmax}}$ and the local fault trace is $68 \pm$ $7^{\circ}$. $\mathrm{S}_{\text {Hmax }}$ is oriented at a relatively consistent angle to the SAF throughout southern California, a result also noted on the basis of a smaller data set by Jones [1988], suggesting that the stress field and fault geometry have evolved in a 


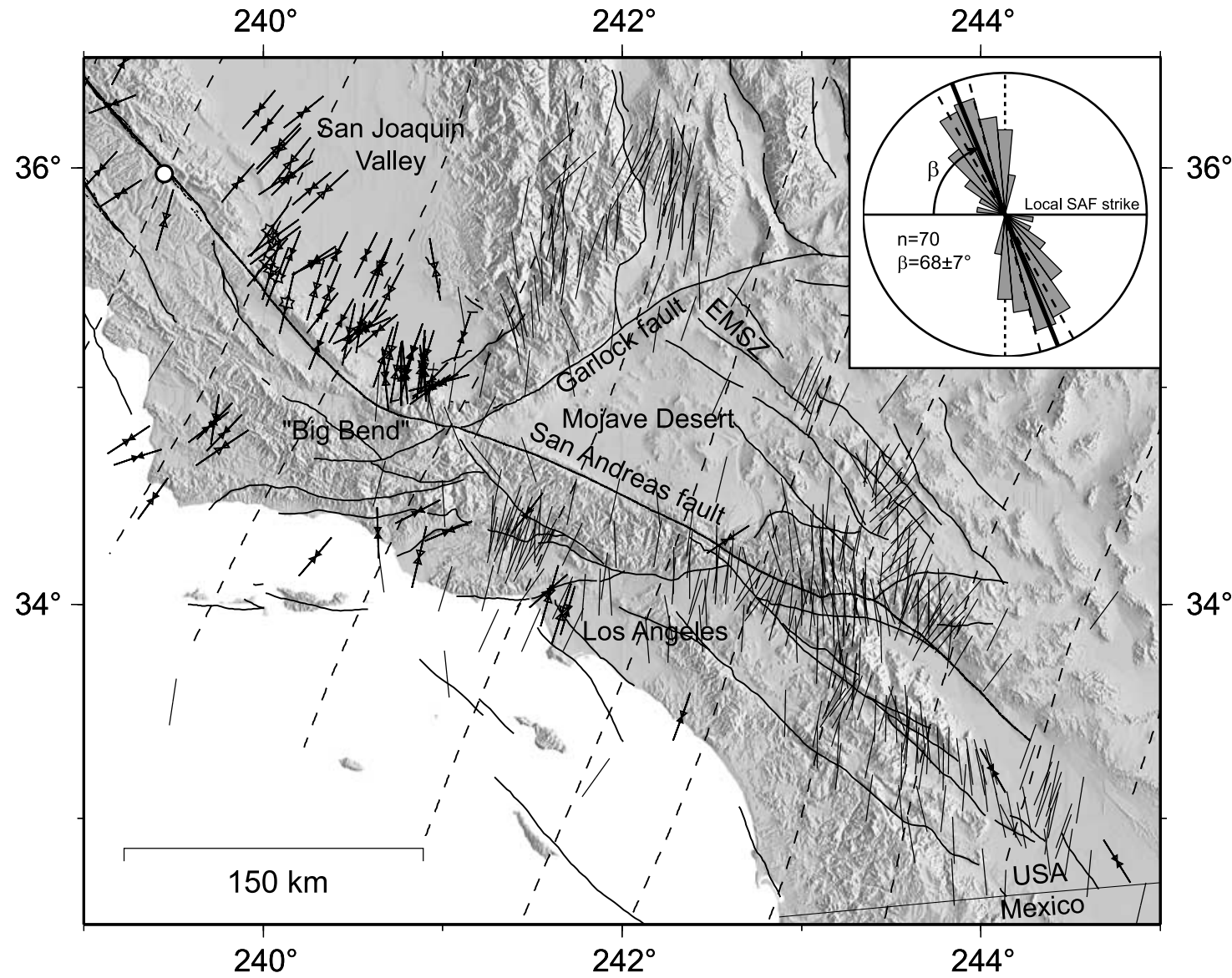

Figure 2. Orientation of the axis of maximum horizontal compression $\left(\mathrm{S}_{\mathrm{Hmax}}\right)$ in southern California. Plain lines indicate $\mathrm{S}_{\mathrm{Hmax}}$ data from earthquake focal mechanism inversions; all other symbols are the same as in Figure 1. The inset summarizes the angle between $\mathrm{S}_{\mathrm{Hmax}}$ and the local fault strike at points within $10 \mathrm{~km}$ of the SAF. EMSZ-Eastern Mojave Shear Zone.

self-organized manner. The corresponding orientation is essentially the same $\left(63 \pm 10^{\circ}\right)$ if only those data within $5 \mathrm{~km}$ of the fault trace are considered (34 data points). Such high $\beta$ angles are not compatible with Andersonian faulting theory based on Byerlee friction and hydrostatic fluid pressures; rather, they support the contention that the SAF is subject to a significant component of fault-normal compression and therefore slips at low shear/normal stress ratios. The average shear and effective normal tractions on planes parallel to the SAF in southern California are estimated to be $\sim 50 \mathrm{MPa}$ and $150 \mathrm{MPa}$, and $\sim 30 \mathrm{MPa}$ and $170 \mathrm{MPa}$, for angles of $61^{\circ}$ and $75^{\circ}$, respectively: these correspond to effective friction coefficients of $\sim 0.2-0.3$.

\section{Discussion and Summary}

[9] The stress data reveal that strike-slip displacement along the SAF and subsidiary structures occurs at an angle of approximately $68^{\circ}$ to the axis of maximum horizontal compression in southern California, and as high as $85^{\circ}$ in central California. In situ stress data and dynamical modeling results from southern and central California exhibit very good agreement in terms of principal tectonic stress directions.

[10] In modeling the contributions of lithospheric buoyancy and internal plate deformation to the horizontal devia- toric stress field, Flesch et al. [2000] made no attempt to match in situ stress data, but the agreement between their computational results and the observed stress directions at regional scales is very good throughout most of California. At distances greater than $10 \mathrm{~km}$ from the SAF fault trace, the average discrepancy between the $\mathrm{S}_{\mathrm{H} \max }$ directions determined from borehole or earthquake data and Flesch et al.'s results is $8^{\circ}$, with the latter being rotated slightly clockwise with respect to the observed stress directions. Nevertheless, it should be noted that there are several areas where the discrepancy is particularly marked. The majority of the locations with high discrepancies are located in one of three distinct clusters: the Big Bend region near $\left(241.0^{\circ} \mathrm{E}\right.$, $\left.34.8^{\circ} \mathrm{N}\right)$, north of the Garlock fault at $\left(241.5^{\circ} \mathrm{E}, 35.4^{\circ} \mathrm{N}\right)$, and near San Bernadino at $\left(242.3^{\circ} \mathrm{E}, 34.2^{\circ} \mathrm{N}\right)$. The Big Bend and San Bernadino "knots" both coincide with appreciable, localized bends in the strike of the SAF's surface trace; the San Bernadino cluster also corresponds to the southernmost rupture of the 1857 Fort Tejon earthquake [Jones, 1988]. The Garlock cluster is at the east end of the source region of the 1952 Kern County earthquake (M7.8), which has been previously interpreted to have substantially affected the local stress field [Castillo and Zoback, 1995].

[11] The fact that the angle between $\mathrm{S}_{\mathrm{Hmax}}$ and the SAF remains approximately constant over a $400 \mathrm{~km}$ distance in 
southern California, despite pronounced changes in the fault's strike, indicates a degree of self-organization or interaction between the tectonic stress field and the fault. If this were not the case, then the relatively uniform orientation of the regional stress field would result in $\beta$ varying systematically with the fault's strike. By comparing discrepancies between the observed and modeled stress orientations close to $(\leq 10 \mathrm{~km})$ and far away from the SAF, we have estimated the effect of this interaction to be equivalent to an anticlockwise rotation of $\mathrm{S}_{\mathrm{Hmax}}$ by less than $\sim 7^{\circ}$.

[12] In southern California, specifically along the section of the SAF that ruptured in the M8+ 1857 Fort Tejon earthquake, Hardebeck and Hauksson [1999] suggested that $\mathrm{S}_{\mathrm{Hmax}}$ rotates by $40^{\circ}$ within $\pm 20 \mathrm{~km}$ of the SAF to an angle at the fault trace of $\beta=45^{\circ}$. This apparent rotation has been used in support of a model positing the SAF's average frictional strength to be consistent with Byerlee friction and hydrostatic fluid pressures [Scholz, 2000], and hence to be comparable to the strength of the adjacent crust. Hardebeck and Hauksson [1999, 2001] suggested to the contrary that while the SAF and adjacent crust have similar strengths, these must necessarily be much lower than predicted using a critically stressed crust model and Byerlee friction.

[13] We are of the opinion that any rotation of $\mathrm{S}_{\mathrm{Hmax}}$ to such low angles must occur over a horizontal distance less than our observation scale of $\sim 5 \mathrm{~km}$. Indeed, the similarity between focal mechanism-based estimates of $\mathrm{S}_{\mathrm{Hmax}}$ near Parkfield and the deepest SAFOD Pilot Hole measurements, which were made only $1.8 \mathrm{~km}$ from the SAF, suggests that any rotation must take place on even smaller horizontal scales. It is important to emphasize that while we cannot rule out average stress orientations at the SAF fault plane itself of $\beta<68^{\circ}$, existing focal mechanism inversion results and borehole data do not substantiate that interpretation. Hardebeck and Hauksson [2001] demonstrated that the focal mechanism stress inversion results they had previously obtained [Hardebeck and Hauksson, 1999] were very similar to those of Townend and Zoback [2001], in which case we conclude that disagreement over the near-field value of $\beta$ stems from the comparison of a small number of results from separate cross-sections with a larger sample of 70 samples collected over a more representative length $(\sim 400 \mathrm{~km})$ of the SAF.

[14] Overall, it is striking that the observed state of stress in southern and central California is so consistent over such a large area, although both the borehole stress measurements and inversions of independent sets of earthquake focal mechanisms reveal gradual lateral stress variations throughout the region. In general, the observed stress field is very similar to Flesch et al.'s [2000] calculations of buoyancy-derived stresses associated with the thermally uplifted Basin and Range province and far-field shear related to Pacific-North America relative plate motion, and consistent with their findings based on regional variations in effective viscosity that the SAF is a mechanically weak boundary. Thus, while GPS data show that motions of the crustal blocks adjacent to the plate boundary are consistent with local plate kinematics, the forces acting within the crust seem to be controlled by relatively far-field processes. The consistently high angle between $\mathrm{S}_{\mathrm{Hmax}}$ and the SAF observed along a $400 \mathrm{~km}$-long section of the fault in southern
California (and the even higher angles seen in the sparser data set further north) demonstrates that the SAF's frictional resistance to slip - though low in both absolute and relative senses - is nevertheless manifest in the tectonic field immediately adjacent to the fault.

[15] Acknowledgments. We are grateful to Lucy Flesch and Bill Holt for making their results available, and to Naomi Boness, Björn Lund, and George Thompson for comments. GMT version 3.3.6 was used to construct both figures.

\section{References}

Abers, G. A., and J. W. Gephart (2001), Direct inversion of earthquake first motions for both the stress tensor and focal mechanisms and application to southern California, J. Geophys. Res., 106(B11), 26,523-26,540.

Byerlee, J. (1978), Friction of rocks, Pure Appl. Geophys., 116, 615-626. Castillo, D. A., and M. D. Zoback (1995), Systematic stress variations in the southern San Joaquin Valley and along the White Wolf fault: Implications for the rupture mechanics of the $1952 M_{S} 7.8$ Kern County earthquake and contemporary seismicity, J. Geophys. Res., 100(B4), 62496264.

DeMets, C., R. G. Gordon, D. F. Argus, and S. Stein (1990), Current plate motions, Geophys. J. Int., 101, 425-478.

Fleitout, L., and C. Froidevaux (1982), Tectonics and topography for a lithosphere containing density heterogeneities, Tectonics, 1, 21-56.

Flesch, L. M., W. E. Holt, A. J. Haines, and B. Shen-Tu (2000), Dynamics of the Pacific-North American plate boundary in the western United States, Science, 287, 834-836.

Fuchs, K., and B. Müller (2001), World stress map of the Earth: A key to tectonic processes and technological applications, Naturwissenschaften, $88,357-371$.

Hardebeck, J. L., and E. Hauksson (1999), Role of fluids in faulting inferred from stress field signatures, Science, 285, 236-239.

Hardebeck, J. L., and E. Hauksson (2001), Crustal stress field in southern California and its implications for fault mechanics, J. Geophys. Res., 106(B10), 21,859-21,882.

Hickman, S., and M. D. Zoback (2004), Stress orientations and magnitudes in the SAFOD Pilot Hole, Geophys. Res. Lett., 31, L15S12, doi:10.1029/ 2004GL020043.

Jones, L. M. (1988), Focal mechanisms and the state of stress on the San Andreas fault in southern California, J. Geophys. Res., 93, 8869-8891.

Jones, C. H., J. R. Unruh, and L. J. Sonder (1996), The role of gravitational potential energy in active deformation in the southwestern United States, Nature, 381, 37-41.

Lachenbruch, A. H., and J. H. Sass (1992), Heat flow from Cajon Pass, fault strength, and tectonic implications, J. Geophys. Res., 97(B4), 49955015 .

Mount, V. S., and J. Suppe (1987), State of stress near the San Andreas fault: Implications for wrench tectonics, Geology, 15, 1143-1146.

Murray, M. H., and P. Segall (2001), Modeling broadscale deformation in northern California and Nevada from plate motions and elastic strain accumulation, Geophys. Res. Lett., 28(22), 4315-4318.

Oppenheimer, D. H., P. A. Reasenberg, and R. W. Simpson (1988), Fault plane solutions for the 1984 Morgan Hill, California, earthquake sequence: Evidence for the state of stress on the Calaveras fault, J. Geophys. Res., 93(B8), 9007-9026.

Provost, A.-S., and H. Houston (2003), Stress orientations in northern and central California: Evidence for the evolution of frictional strength along the San Andreas plate boundary system, J. Geophys. Res., 108(B3), 2175, doi:10.1029/2001JB001123.

Saffer, D. M., B. A. Bekins, and S. Hickman (2003), Topographically driven groundwater flow and the San Andreas heat flow paradox revisited, J. Geophys. Res., 108(B5), 2274, doi:10.1029/2002JB001849.

Schaff, D. P., G. H. R. Bokelmann, G. C. Beroza, F. Waldhauser, and W. L. Ellsworth (2002), High-resolution image of Calaveras fault seismicity, J. Geophys. Res., 107(B9), 2186, doi:10.1029/2001JB000633.

Scholz, C. H. (2000), Evidence for a strong San Andreas fault, Geology, 28, $163-166$.

Townend, J., and M. D. Zoback (2000), How faulting keeps the crust strong, Geology, 28, 399-402.

Townend, J., and M. D. Zoback (2001), Implications of earthquake focal mechanisms for the frictional strength of the San Andreas fault system, in The Nature and Significance of Fault Zone Weakening, edited by R. E. Holdsworth et al., Geol. Soc. London Spec. Publ., 186, 13-21.

Working Group on Earthquake Probabilities (1999), Earthquake probabilities in the San Francisco Bay region: 2000-2030-A summary of findings, U. S. Geol. Surv. Open File Rep., 99-517, 60 pp. 
Zoback, M. D., and G. C. Beroza (1993), Evidence for near-frictionless faulting in the 1989 (M6.9) Loma Prieta, California, earthquake and its aftershocks, Geology, 21, 181-185.

Zoback, M. L. (1992), First- and second-order patterns of stress in the lithosphere: The World Stress Map Project, J. Geophys. Res., 97(B8), $11,703-11,728$

Zoback, M. D., et al. (1987), New evidence for the state of stress on the San Andreas fault system, Science, 238, 1105-1111.
Zoback, M. L., et al. (1989), Global patterns of tectonic stress, Nature, 341, $291-298$

J. Townend, School of Earth Sciences, Victoria University of Wellington, P.O. Box 600, Wellington, New Zealand. (john.townend@vuw.ac.nz)

M. D. Zoback, Department of Geophysics, Stanford University, Stanford, CA 94305-2215, USA. (zoback@pangea.stanford.edu) 